\title{
Anterior cervical osteophytosis as a cause of dyspnoea and stridor
}

\author{
Hugo Jorge Casimiro, ${ }^{1,2}$ Joana Carreira, ${ }^{1}$ Beatriz Navarro, ${ }^{1}$ Mário Parreira ${ }^{1}$
}

'Department of Internal Medicine, Centro Hospitalar de Setubal EPE, Setúbal, Portugal ${ }^{2}$ Instituto de Histologia e Biologia do Desenvolvimento, Universidade de Lisboa Faculdade de Medicina, Lisboa, Portugal

\section{Correspondence to} Dr Hugo Jorge Casimiro, hugojorgecasimiro@gmail.com

Accepted 1 August 2017

\section{CrossMark}

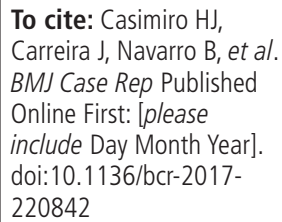

\section{DESCRIPTION}

A 77-year-old man with no history of respiratory disease presented with a 12-hour history of dyspnoea, stridor, non-productive cough and rhinorrhoea. He denied other symptoms such as dysphagia and dysphonia. Physical examination showed diminished vesicular breath sounds and stridor, although there were no vocal cord abnormalities in the laryngoscopic evaluation. The laboratory results and the posteroanterior chest radiograph revealed no significant abnormalities.

In order to exclude an airway obstruction, a cervical radiograph was obtained. The exam showed anterior osteophytosis involving the lower segment of the cervical spine (figure 1). A CT scan confirmed the diagnosis, revealing a tracheal narrowing due to anterior osteophytosis between C5 and C7 associated with thickening of adjacent soft tissues (figure 2).

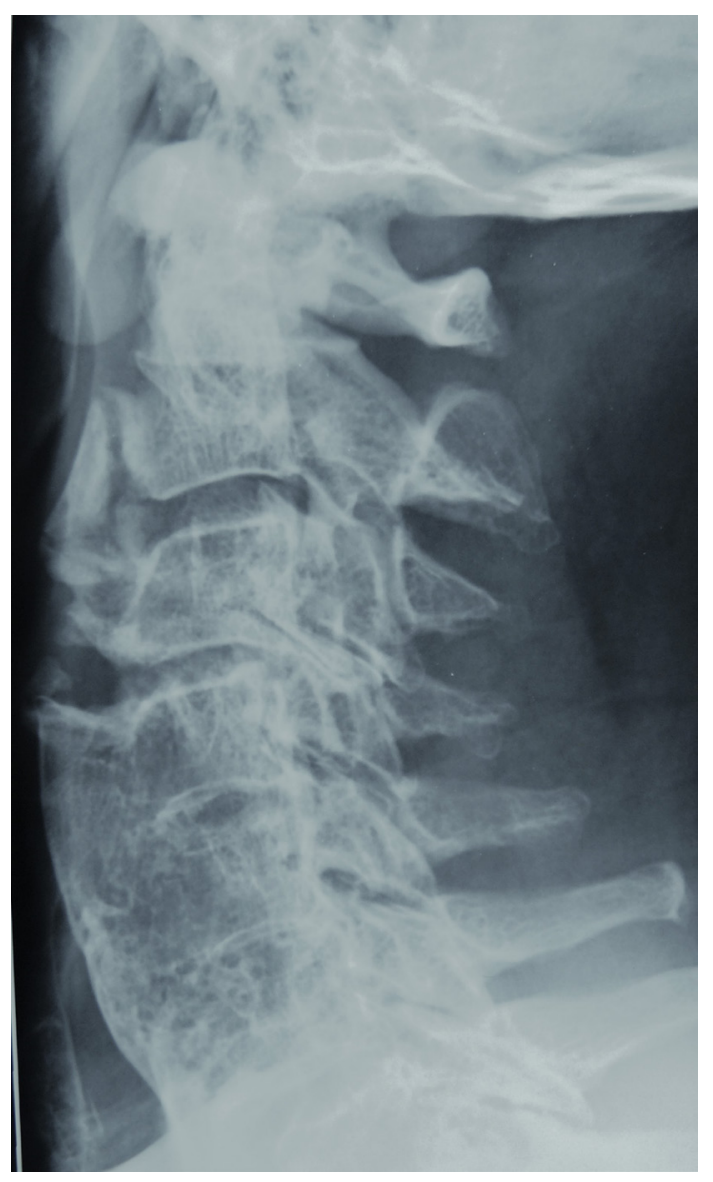

Figure 1 Cervical radiograph showing extensive osteophytosis in the anterior aspects of the lower cervical vertebrae.

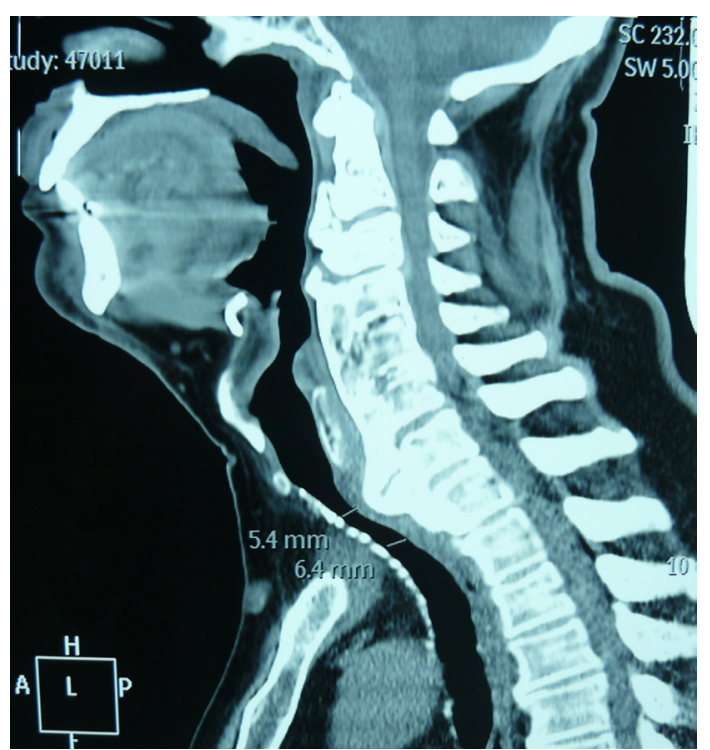

Figure 2 Cervical CT scan showing external compression of the upper airway due to anterior cervical osteophytosis.

The sudden onset of symptoms was probably related to a viral infection. The patient's symptoms improved after he was given systemic corticosteroids. He later underwent surgical correction with resection of the osteophytes. Since then he remains asymptomatic and with no need of further intervention.

Anterior cervical osteophytosis is common among elderly people and is usually asymptomatic and does not need any specific approach. ${ }^{1}$ When symptoms develop, dysphagia for solid food is the most common one. In our case, the patient had dyspnoea and stridor but without dysphagia, which was an unusual presentation. This was due to the lower level of the osteophytes that spared the laryngeal and pharyngeal structures and instead caused an extrinsic compression of the airway.

\section{Learning points}

- Anterior cervical osteophytosis is common among elderly people and is often assymtopmatic.

- Dyspnoea and stridor may occur when external compression of the upper airway develops, although they are rare without dysphagia.

- Even when dysphagia is absent, anterior cervical osteophytes can be a cause of dyspnoea and stridor in patients. 
In patients with substantial compression, such as this one, surgical intervention is the best treatment available. ${ }^{2}$

Contributors HJC was responsible for the overall content, including planning, conduct and reporting of the work. JC was responsible for the planning and conduct of the work, including literature search, figures and data collection. BN was responsible for conduct and reporting of the work. MP was responsible for the reporting of the work.

Competing interests None declared.

Patient consent Obtained.
Provenance and peer review Not commissioned; externally peer reviewed.

(C) BMJ Publishing Group Ltd (unless otherwise stated in the text of the article) 2017. All rights reserved. No commercial use is permitted unless otherwise expressly granted.

\section{REFERENCES}

1 Seo JW, Park JW, Jang JC, et al. Anterior cervical osteophytes causing dysphagia and paradoxical vocal cord motion leading to dyspnea and dysphonia. Ann Rehabil Med 2013:37:717-20.

2 Chen YR, Sung K, Tharin S. Symptomatic anterior cervical osteophyte causing dysphagia: case report, imaging, and review of the literature. Cureus 2016;8:e473.

Copyright 2017 BMJ Publishing Group. All rights reserved. For permission to reuse any of this content visit

http://group.bmj.com/group/rights-licensing/permissions.

BMJ Case Report Fellows may re-use this article for personal use and teaching without any further permission.

Become a Fellow of BMJ Case Reports today and you can:

- Submit as many cases as you like

- Enjoy fast sympathetic peer review and rapid publication of accepted articles

Access all the published articles

Re-use any of the published material for personal use and teaching without further permission

For information on Institutional Fellowships contact consortiasales@bmjgroup.com

Visit casereports.bmj.com for more articles like this and to become a Fellow 